\title{
HIDES, LEATHER, BOOTS AND SHOES AND THE TARIFF
}

\author{
By A. Augustus Healy, \\ Vice-President United States Leather Company, New York.
}

As at present conducted, tanning hides into leather and manufacturing leather into boots and shoes are separate industries, but for the purposes of this article they may be considered as one. Together they form a very great industry. There is none in the United States which is naturally more capable of successful development. There is none which has been more impeded by the tariff. This great industry now calls loudly for a reduction of the tariff. Especially does it call for the abolition of the duty of 15 per cent imposed on hides by the Dingley tariff of 1897 .

Hides are its raw material. Before 1897 they had always been free of duty, excepting the Civil War tax of Io per cent, which was repealed in 1873 . The effect of the duty on hides during the past ten years has been very injurious-injurious to the hundreds of thousands engaged in the industry and to the millions of consumers of boots and shoes. Here is a necessity of life whose manufacture is smitten with a blighting tax at the very point of its origin. The United States does not produce more than two-thirds of the number of hides required therein for making leather. Even with a 5 per cent duty, one-third of the needed supply must be imported from various parts of the world, principally from South America. The situation, therefore, is one to make such an impost upon a raw material like hides peculiarly disastrous to the prosperity of the industry, while peculiarly advantageous to the few who benefit from it. Where so large a proportion must be imported, the effect of the duty is not only to raise the cost of the imported supplies, but to give an advanced and artificial price to hides produced within the United States. These are concentrated for the most part in the hands of a few owners, to whom this advantage inures. The farmer or cattle-grower gets little or no benefit from the artificial price of hides, because, being a by-product and constituting but a small part of the value of cattle when slaughtered, the

(295) 
increased price of the hide does not enter perceptibly into the amount received for cattle going to market. The injury, however, to the leather and shoe industry in putting it at so great a disadvantage in competing with foreign nations in the hide markets of the world for the acquisition of its raw material is enormous. All those engaged therein realize this too well in its retarded growth and minimized profits.

This injury was foreseen when the duty was imposed in 1897 , and a delegation of leather and shoe people went to Washington, while the new tariff bill was still in committee, and strongly argued against the placing of a duty on hides at a hearing given by the committee on ways and means. As the proposed duty was an entirely new feature in the tariff bill, hides having been free of duty for twenty-five years, and as there appeared to be no demand for such a duty, it was to be supposed that Congress would require cogent and positive arguments in its favor before confirming a new impost to which strenuous objection had been made. No one, however, appeared at the hearing in favor of the duty. The shoe and leather delegation were politely promised that full consideration would be given to the arguments advanced in opposition, and went away hoping and believing that they had won their case, because, as it had been developed at the hearing, it seemed to be a very clear and one-sided one in their favor. But some secret influence was at work which did not come into the light, and the duty was imposed without public reasons in its favor and against the protests of the representatives of the great industry which it was bound vitally to affect. That duty has been ever since a source of constant and increasing dissatisfaction to all the leather and shoe manufacturers of the United States.

In November, I905, a delegation of more than thirty individuals, representing more than three-fourths in volume of these combined industries, visited Washington and laid their case before President Roosevelt, in the hope that he might be induced, by the urgency of the matter, to exert his official influence with Congress, at its then forthcoming session, in favor of the immediate repeal of the duty on hides. Nothing, however, resulted from this interview beyond the admission from the President of the importance of the subject and that it had given him anxious thought. Evidently he was then absorbed in other matters which he deemed of more consequence. 
Besides, both President and Congress seemed to fear that any tariff change, even to correct a mistake that had been made, might result in opening up the whole subject of tariff revision, which was considered by them most undesirable at that time. The duty on hides remained, and somewhat later, in consequence of greater scarcity and the impediment offered to their importation by the tariff, the price of hides saared to an unprecedented height, causing disorder and confusion in the related industries, which intensified the result of the violent reaction and adverse conditions following the panic of last year. The duty on hides still continues to exert its adverse influence upon the leather and shoe industries, and those engaged therein are now turning their eyes to the extra session of Congress, which has been suggested immediately to follow the inauguration of a new President, in the hope that relief will then be afforded by repeal.

It is this particular measure of relief which all those engaged in the manufacture of leather and boots and shoes have in mind when thinking of tariff revision in connection with their own industry. Indeed, this removal of the tax upon their raw material cannot be denied them, with any justice, by Congress, when it is remembered that they are further handicapped in their business by the high duties which the tariff, in general, imposes upon imports. These duties have the effect of adding to their cost of production and at the same time diminish the foreign demand for their manufactured product, without giving them in return any corresponding benefit. The tariff adds to the large item of freight upon their bulky materials and upon their finished goods. It increases the cost of buildings, equipment, machinery and general supplies. In short, it adds to the cost of the manufactured article and at the same time, like the duty on the raw material, increases the quantity of capital required for a given amount of production. Then, again, as both leather and shoes are exportable articles, the demand abroad for them is restricted by the generally high duties of the present tariff, which prevents the importation of foreign commodities that otherwise would be sent to us in exchange for a larger exportation of leather and boots and shoes. As President McKinley said, in his last public utterance at Buffalo, "We cannot sell if we will not buy."

It is, therefore, most desirable, in the interest of this industry (297) 
and its further development, that there should be a general reduction of the present very high duties on imports, supplemented by reciprocity treaties with foreign countries, that would enable us to send them larger quantities of leather and shoes, which this country is specially adapted to produce, in return for various commodities in the production of which the natural advantage is with them. The manufacture of leather and shoes, in which our people are particularly skillful, is here capable of enormous development along these lines.

On the other hand, unless tariff changes be made in the direction of liberality, there is imminent danger that we shall lose the valuable export trade in these articles which we already possess. The markets of continental Europe are gradually being closed by exclusive duties, and it is now highly probable that England, our principal foreign customer for leather and shoes, will soon shut her ports to us unless her present liberal policy be met with tariff concessions on the part of the United States. An enlightened policy, such as is here suggested, it would surely seem to be part of wisdom for Congress to adopt, rather than one which, by heavy tariff duties, the avoidance of reciprocity treaties and a vicious tax upon raw material, tends to nullify, in part, the great advantage which the country possesses for the production of leather and its manufacture into boots and shoes.

The great oak, hemlock and chestnut forests of the United States supply abundant material of the best kind for the tanning of leather. Improved methods, the introduction of machinery and the employment of chemical analysis have aided greatly in reducing the cost and improving the quality of the product. Our shoe manufacturers are admitted to be the best in the world. Thorough organization, skill in making lasts adapted to all kinds of feet and the employment of machinery to an extraordinary degree, which is operated with a perfection and speed unequaled in any other country, have given to the United States the first place among nations in the manufacture of boots and shoes. Notwithstanding these advantages, the combined shoe and leather industry, as a whole, has not had the increase and development to which it was naturally entitled, nor has it yielded profits commensurate with those of other more favored industries. The shoe and leather manufacturers have never asked for protection or governmental aid. 
They do ask now, however, to be relieved from the burdens which the tariff lays upon their industry.

Why should not the country be permitted to expand its industrial life along the line of least resistance, and why should not these shoe and leather industries be allowed full scope for the growth and development to which they are invited by natural conditions and the genius of our people, and thus be enabled to give profitable employment to many thousands more of our citizens? 